\title{
Development of a Virtual Learning Environment Model to Fortify Life Skills for Teenage of Thailand
}

\author{
Songsak Haowharn \\ Faculty of Education, Mahasarakham University, Mahasatakham, Thailand \\ Chaiyot Ruangsuwan (Corresponding author) \\ Faculty of Education, Mahasarakham University, Mahasatakham, Thailand \\ E-mail: drchaiyot@msu.ac.th; drchaiyot@hotmail.com
}

Received: December 9, 2021

Accepted: January 17, 2022 Published: February 8, 2022

doi:10.5296/jei.v8i1.19314

URL: https://doi.org/10.5296/jei.v8i1.19314

\begin{abstract}
Developing a virtual learning environment model to fortify life skills for teenagers in Thailand entails an application between information technology and communication for managing an instruction in life skills and expanding the opportunities of Thai teenagers to have access to the skills contents. The objectives of research were to develop the virtual learning environment model to fortify life skills for teenagers in Thailand. There were 4 sample groups: 176 specialists in life skills; 45 teenagers at the age of 12-18 years; 5 experts in related fields; and 9 specialists in related fields. There were 4 components of the model of virtual learning environment to fortify life skills for Thai teenagers: input, processes, output, and feedback. The model of virtual learning environment to fortify life skills for Thai teenagers gained the process and outcome was 89.66/90.90. The result indicated that the score of process of model was $89.66 \%$ and the score of product of model was $90.90 \%$, and the efficiency index of 0.8063 . The satisfaction towards virtual learning environment is fluctuating but tend to be useful for learners. This virtual learning environment model can use and employ for implementing in education.
\end{abstract}

Keywords: Learning environment, Learning skills, Life skills, Virtual learning

\section{Introduction}

Life skills have gained increasing interest at the international level as they are an asset for the life protection of children and teenagers. It is suggested that life skills are best taught to persons from age 6-18 years, an age range critical for learning development (Elias \& Kress, 
1994; Pierce et al., 2017). Moreover, both private and government sectors are aware of the importance of life skills, which have been used as guidelines for the solution of several problems such as poor school grades, drug use, alcohol consumption, and risky behaviors (Hodge et al., 2013; Bean et al., 2018).

Teaching life skills to youngsters is, therefore, very essential because these skills can be developed through individual experience and training. The primary aim of life-skills teaching is to develop the right attitude by youngsters, which will eventually lead to the development of desired behaviors. Recently, life skills subjects have been added to Thailand's basic education, and most instruction is usually conducted by several sectors in a supplement to normal classroom learning in the form of life-skills learning camps, which is an informal or convenience mode of learning, (Chan et al., 2011; Prasertcharoensuk et al., 2015; Dostál, et al., 2017; Chintaradeja, 2021).

Nowadays, computer technology, especially information communication and technology (ICT), has been much developed and has metamorphosed instructional programs to become learning systems, which has consequentially made teaching and learning become more effective. The network learning system is an innovative way of providing more effective instruction. It has also created a number of modern modes of learning such as blended learning and hybrid learning (Akarawang et al., 2015; Akarawang et al., 2016; Dziuban et al., 2018; Rasheed et al., 2020). Recognizing the significance of life skills instruction, this study was conducted to develop a virtual learning environment (VLE) to fortify the life skills of teenagers and to offer another access to learning life skills for teenagers (Bogusevschi et al., 2020; Lacka et al., 2021).

The study aimed to encourage the use of ICT to promote life-long learning in correspondence with Thailand's ICT Policy Framework (Vu, 2017; Sathithada, 2018). The objectives of this research are then to develop a learning environment to fortify life skills learning for Thai teenagers. The findings can help educators to improve the quality of education and lead virtual learning environment into authentic learning.

\section{Method}

\subsection{Procedural Setting}

The study employed a research and development method in which concepts and theories related to virtual learning environment to fortify life skills for Thai teenagers were studied. Moreover, enquiries were made to experts in life-skills teaching in secondary schools and community hospitals in Thailand about the current situation and demand for virtual learning environment model to fortify life skills for 300 teenage learners. The study concerns the design and development of a model to fortify the life skills of Thai teenagers, which model was proposed to 5 experts for content validation. After the revision according to the experts' suggestions, the result was the implementation stage of the virtual learning environment model. Then the model was implemented with a group of 45 participants aged 12-18 years, who had been recruited using a simple random method. 


\subsection{Research Instruments}

The research instrument can be divided into each stage of study (Table 1). The instruments were correct its validity by experts in fields of educational technology, curriculum and instruction, and education evaluation and assessment. Achievement test and satisfaction towards learning were validated and correct it appropriateness, then pilot study with teenage learners for reliability with 45 participants aged 12-18 years.

Table 1 Research instruments

\begin{tabular}{|c|c|c|}
\hline Stage 1 & Stage 2 & Stage 3 \\
\hline $\begin{array}{l}\text { (1) Document analysis form of } \\
\text { concepts and theories related to } \\
\text { life skills instruction } \\
\text { management for Thai teenagers. } \\
\text { (2) A questionnaire on the } \\
\text { current situation and demand for } \\
\text { the use of virtual learning } \\
\text { environment model for life } \\
\text { skills learning of Thai teenagers. }\end{array}$ & $\begin{array}{l}\text { (1) A draft of the proposed } \\
\text { virtual learning environment } \\
\text { model to fortify life skills for } \\
\text { Thai teenagers } \\
\text { (2) An evaluation form of the } \\
\text { proposed virtual learning } \\
\text { environment model to fortify } \\
\text { life skills for Thai teenagers }\end{array}$ & $\begin{array}{l}\text { (1) Online life skills lessons } \\
\text { comprising all components of the } \\
\text { prototype virtual learning } \\
\text { environment model to fortify life } \\
\text { skills for Thai teenagers. } \\
\text { (2) A 30-item of multiple choice } \\
\text { test used for pre- and post-testing } \\
\text { of life skills to assess learner } \\
\text { achievements and retention before } \\
\text { and after taking the online lessons. } \\
\text { (3) A 5-point Liker scale of } \\
\text { questionnaire of learner } \\
\text { satisfaction towards the lessons. }\end{array}$ \\
\hline
\end{tabular}

\subsection{Data Collection and Analysis}

The data collection process for the presented study started with syntheses of documents, concepts, and theories related to life skills instruction for Thai teenagers. The process was followed by conducting a survey with the sample group about current situations and demand for virtual learning environment models to fortify life skills learning of Thai teenagers. Then, the created virtual learning environment model to fortify life skills learning of Thai teenagers was submitted to the experts for evaluation. Then, model was revised in accordance with the experts' comments and suggestions.

\section{Result and Discussion}

The virtual learning environment model to the fortify life skills learning of Thai teenagers developed by the researchers was comprised of 4 components, namely: (1) inputs consisting learners, teacher, philosophy, life-skills contents, objectives, instructional media, learning resources, the Internet system, evaluation system, and learning tracking system; (2) process consisting of participatory learning and web-based instruction; (3) outputs comprising 
learning achievements and abilities; and (4) feedback from the three groups of participants for the revisions of the developed virtual learning environment model as shown in Figure 1.

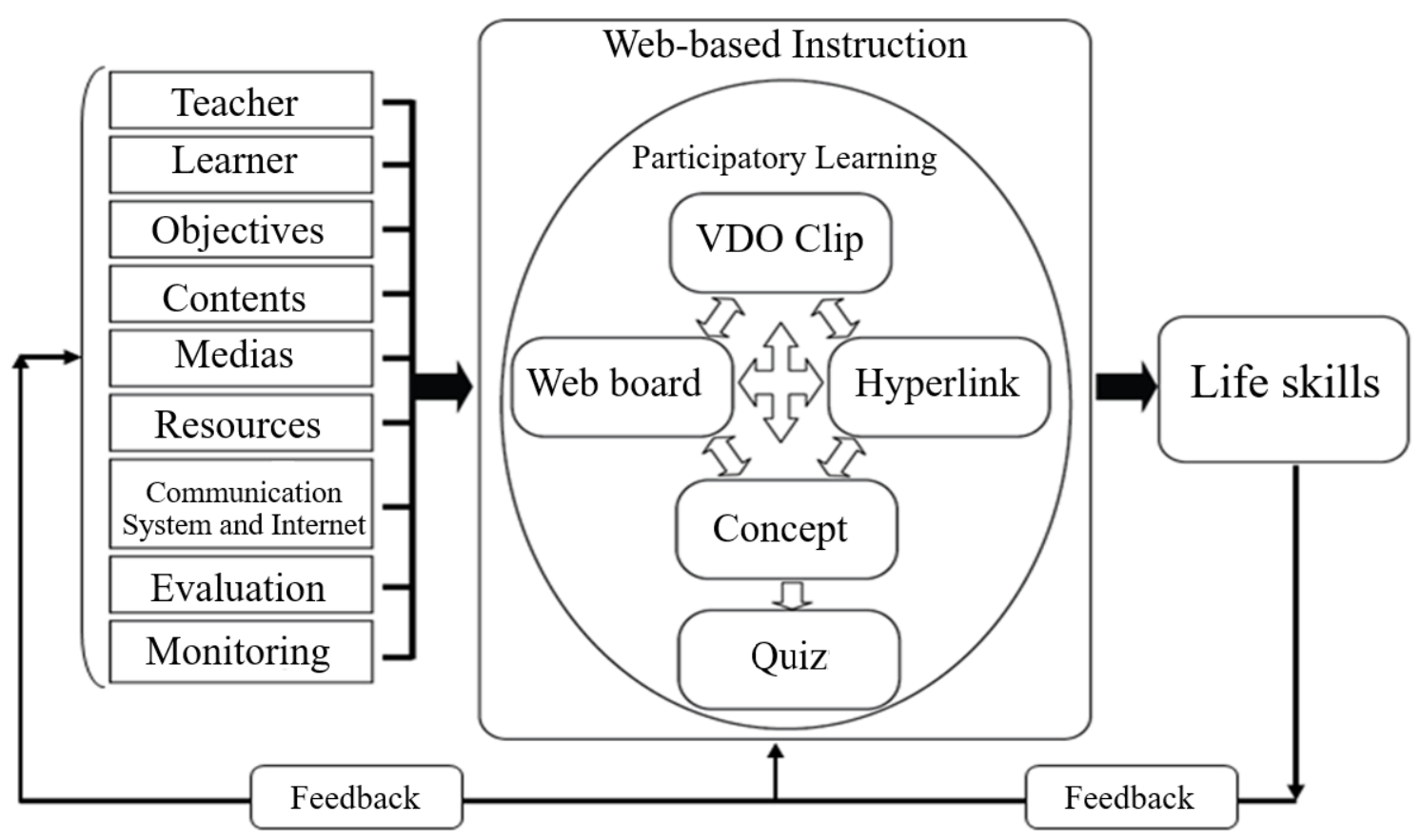

Figure 1 Virtual learning environment model to fortify the life skills learning of Thai teenagers

The results of the study suggest that there is a high demand for virtual learning environment models to support life skills learning of Thai teenagers. A focus group of respondentsteachers of subjects in which life skills contents are included as specified by the Ministry of Education and speakers who organize activities to promote life skills to community hospitals nationwide- were recruited for the study in order to probe into the core of the problems of life skills instruction. The findings indicate that life skills lessons need a revision to make the contents up-to-date (Orey \& Rosa, 2018; Ryan \& Poole, 2019).

However, a number of limitations have been a major barrier for teachers going through all the contents of life skills. Regarding this issue, some sample teachers of the study reported that they had suggested their students to study further from websites. In other words, they had recommended to their students a range of websites with life skills lessons as an additional resource of learning. The development of the VLE model to fortify life skills learning for Thai teenagers was carried out on the basis of ADDIE Model consisting of 5 phases namely: Analysis, Design, Development, Implementation, and Evaluation (Ruangsuwan, 1992; Ruangsuwan, 2014; Baharuddin, 2018; Trust \& Pektas, 2018).

The efficiency of the learning process and product of the developed virtual learning environment model was $89.66 / 90.90$ with the efficiency index (E.I.) of 0.8063 . The learners 
obtained significant higher learning achievements on life skills. The findings from the development phase of the virtual learning environment model, suggest that the lessons covered all the contents of life skills as summarized in Tables 2 and 3.

Table 2 Learning achievement

\begin{tabular}{|l|l|l|l|}
\hline & Pre-test & Cumulative score in each unit of learning $\left(\mathrm{E}_{1}\right)$ & Post-test $\left(\mathrm{E}_{2}\right)$ \\
\hline Mean & 15.90 & 26.87 & 27.27 \\
\hline SD & 3.80 & 2.94 & 2.15 \\
\hline
\end{tabular}

The model of virtual learning environment to fortify life skills for Thai teenagers gained the process and product was $89.66 / 90.90$. The result indicated that the score of process of model was $89.66 \%$ and the score of product of model was $90.90 \%$,

Table 3 Analysis of online lessons efficiency

\begin{tabular}{|l|l|l|l|l|}
\hline Number of students & Full score & Pre-test score & Post-test score & Efficiency index \\
\hline 30 & 30 & 15.90 & 27.27 & 0.8063 \\
\hline
\end{tabular}

The efficiency index (E.I.) of 0.8063. The learners obtained significant higher learning achievements on life skills. The findings from the development phase of the virtual learning environment model, suggest that the lessons covered all the contents of life skills.

The analysis phase involved the study of conceptual framework and theories related to virtual learning environments to enhance life skills learning for Thai teenagers, document analysis, and previous research, as well as studying the current situation of life skills learning through a survey. The results showed that the use of online resources is highly recommended by life skills teachers, and it is agreed that online lessons can effectively assist normal classroom instruction (Ekici, 2017).

In the design phase, a virtual learning environment model to fortify life skills learning for Thai teenagers was created. The results of this phase recognised that the virtual learning environment model comprised three components, namely: (1) inputs consisting learners, teacher, philosophy, life-skills contents, objectives, instructional media, learning resources, the Internet system, evaluation system, and learning tracking system; (2) process consisting of participatory learning and web-based instruction; (3) outputs comprising learning achievements and abilities including knowledge, attitude, and skills; and (4) feedback from the three groups of participants for the revisions of the developed virtual learning 
environment model.

The developed virtual learning environment model was approved by the experts in field of study as being appropriate. In the next stage, the implementation phase, the virtual learning environment model was used with the sample group. The result show that the implemented virtual learning environment model could increase students' learning satisfaction towards model (Table 4).

Table 4 Satisfaction of learners with developed models

\begin{tabular}{|c|c|c|}
\hline Item & Mean & $\begin{array}{l}\text { Level of } \\
\text { satisfaction }\end{array}$ \\
\hline 1. Learners understand the content of life skills lessons offered in the lesson. & 3.56 & High \\
\hline 2. Life skills lessons give learners more knowledge. & 3.81 & High \\
\hline 3. Life skills lessons offer interesting content. & 4.20 & High \\
\hline 4. Life skills lessons make learners enjoy learning life skills more. & 4.00 & High \\
\hline 5. Life skills lessons allow people to learn how to deal with problems. & 3.21 & Moderate \\
\hline 6. Life skills lessons can be complementary lessons in their spare time. & 4.70 & Highest \\
\hline 7. Life skills lessons make learners creative. & 3.44 & Moderate \\
\hline 8. The screen design of life skills lessons is interesting. & 3.03 & Moderate \\
\hline 9. The size, design, and color of the letters used in life skills lessons are appropriate. & 3.00 & Moderate \\
\hline $\begin{array}{l}\text { 10. The language used in life skills lessons makes it easier to understand the lesson } \\
\text { content. }\end{array}$ & 4.14 & High \\
\hline $\begin{array}{l}\text { 11. Learner is satisfied that, at the time of answering, the question correctly will } \\
\text { receive an instant compliment. }\end{array}$ & 4.37 & High \\
\hline 12. The learner is satisfied when receiving immediate advice. & 4.51 & Highest \\
\hline 13. Learners are satisfied when taking the test and can know the score immediately. & 4.50 & Highest \\
\hline 14. Learner like this lesson because it can promote life skills. & 4.01 & High \\
\hline 15. Learners agree to create life skills lessons of this nature in other contents. & 4.66 & Highest \\
\hline Overall & 3.94 & High \\
\hline
\end{tabular}

The satisfaction towards virtual learning environment from field study revealed that learners had fluctuating satisfaction levels. The items which are at the highest level are: that life skills lessons can be complementary lessons in their spare time; that learners agree to create life skills lessons of this nature in other contents; and that the learner is satisfied when receiving 
immediate advice in the following. These findings are useful for preparation program and professional development to establish a virtual learning environment in the classroom (Prachagool et al., 2016; Nuangchalerm, 2020). Teachers should understand how to integrate technology and modern classroom as it is in a new era. In summary, the virtual learning environment model developed by the researchers is an appropriate and effective tool to fortify life skills learning for Thai teenagers.

\section{Recommendation}

Learners' range of ages (12-18 years old) should be considered in developing an instructional model for life skills learning. The lessons should be suitable for the learner's age. It is advisable that investigations be undertaken to discover whether the effects of virtual learning environment models differ across different age groups of learners, and if there are any corrections, how they differ. There should be studies on the development of instructional models for life skills learning that suit learners in different age groups. Issues, components, procedure, and methods of the virtual learning environment model to fortify life skills learning of Thai teenagers should be further studied in order to improve its effectiveness and efficiency.

\section{References}

Akarawang, C., Kidrakran, P., \& Nuangchalerm, P. (2015). Enhancing ICT competency for teachers in the Thailand basic education system. International Education Studies, 8(6), 1-8. https://doi.org/10.5539/ies.v8n6p1

Akarawang, C., Kidrakran, P., \& Nuangchalerm, P. (2016). Developing ICT competency for Thai teachers through blended training. Journal of Education and Learning, 10(1), 15-21. https://doi.org/10.11591/edulearn.v10i1.2830

Baharuddin, B. (2018). ADDIE model application promoting interactive multimedia. IOP Conference Series: Materials Science and Engineering, 306(1), 012020. https://doi.org/ 10.1088/1757-899X/306/1/012020

Bean, C., Kramers, S., Forneris, T., \& Camiré, M. (2018). The implicit/explicit continuum of life skills development and transfer. Quest, 70(4), 456-470. https://doi.org/10.1080/00336297. 2018.1451348

Bogusevschi, D., Muntean, C., \& Muntean, G. M. (2020). Teaching and learning physics using 3D virtual learning environment: A case study of combined virtual reality and virtual laboratory in secondary school. Journal of Computers in Mathematics and Science Teaching, $39(1), 5-18$.

Chan, R. M., Lau, P. S., \& Yuen, M. (2011). Interrelationships among teacher care, students' life skills development, and academic achievement: Implications for school guidance work. Asian Journal of Counselling, 18(1), 63-94.

Chintaradeja, P. (2021). 'Coming out'of Thai students in the Discourse of Higher Education. Journal of Green Learning, 1(2), 34-40. https://doi.org/10.53889/jgl.v1i2.34 
Dostál, J., Wang, X., Steingartner, W., \& Nuangchalerm, P. (2017). Digital intelligence-new concept in context of future school of education. Proceedings of ICERI2017 Conference November 16-18, 2017. https://doi.org/10.21125/iceri.2017.0997

Dziuban, C., Graham, C. R., Moskal, P. D., Norberg, A., \& Sicilia, N. (2018). Blended learning: the new normal and emerging technologies. International Journal of Educational Technology in Higher Education, 15(1), 1-16. https://doi.org/10.1186/s41239-017-0087-5

Ekici, D. I. (2017). The use of Edmodo in creating an online learning community of practice for learning to teach science. Malaysian Online Journal of Educational Sciences, 5(2), 91-106.

Elias, M. J., \& Kress, J. S. (1994). Social decision-making and life skills development: A critical thinking approach to health promotion in the middle school. Journal of School Health, 64(2), 62-66. https://doi.org/10.1111/j.1746-1561.1994.tb06180.x

Hodge, K., Danish, S., \& Martin, J. (2013). Developing a conceptual framework for life skills interventions. The Counseling Psychologist, 41(8), 1125-1152. https://doi.org/10.1177/ 0011000012462073

Lacka, E., Wong, T. C., \& Haddoud, M. Y. (2021). Can digital technologies improve students' efficiency? Exploring the role of Virtual Learning Environment and Social Media use in Higher Education. Computers \& Education, 163, 104099. https://doi.org/10.1016/ j.compedu.2020.104099

Nuangchalerm, P. (2020). TPACK in ASEAN perspectives: Case study on Thai pre-Service teacher. International Journal of Evaluation and Research in Education, 9(4), 993-999. https://doi.org/10.11591/ijere.v9i4.20700

Orey, D. C., \& Rosa, M. (2018). Developing a mathematical modelling course in a virtual learning environment. ZDM, 50(1), 173-185. https://doi.org/10.1007/s11858-018-0930-8

Pierce, S., Gould, D., \& Camiré, M. (2017). Definition and model of life skills transfer. International Review of Sport and Exercise Psychology, 10(1), 186-211. https://doi.org/ 10.1080/1750984X.2016.1199727

Prachagool, V., Nuangchalerm, P., Subramaniam, G., \& Dostal, J. (2016). Pedagogical decision making through the lens of teacher preparation program. Journal for the Education of Gifted Young Scientists, 4(1), 41-52. https://doi.org/10.17478/JEGYS.2016116351

Prasertcharoensuk, T., Somprach, K. L., \& Ngang, T. K. (2015). Influence of teacher competency factors and students' life skills on learning achievement. Procedia-Social and Behavioral Sciences, 186, 566-572. https://doi.org/10.1016/j.sbspro.2015.04.021

Rasheed, R. A., Kamsin, A., \& Abdullah, N. A. (2020). Challenges in the online component of blended learning: A systematic review. Computers \& Education, 144, 103701. https://doi.org/10.1016/j.compedu.2019.103701

Ruangsuwan, C. (1992). Instructional system design and development (2nd ed.). Bangkok: 
Odeon Store.

Ruangsuwan, C. (2014). Courseware and web-based design and development (15th ed.). Khon Kaen: Khonkaen Printing.

Ryan, E., \& Poole, C. (2019). Impact of virtual learning environment on students' satisfaction, engagement, recall, and retention. Journal of Medical Imaging and Radiation Sciences, 50(3), 408-415. https://doi.org/10.1016/j.jmir.2019.04.005

Sathithada, K. (2018). E-leadership of Thailand's higher education leaders in 2027. Educational Administration Innovation for Sustainable Development (pp. 263-268). CRC Press. https://doi.org/10.1201/9780203701607-38

Trust, T., \& Pektas, E. (2018). Using the ADDIE model and universal design for learning principles to develop an open online course for teacher professional development. Journal of Digital Learning in Teacher Education, 34(4), 219-233. https://doi.org/10.1080/ 21532974.2018.1494521

Vu, K. M. (2017). ICT diffusion and production in ASEAN countries: Patterns, performance, and policy directions. Telecommunications Policy, 41(10), 962-977. https://doi.org/10.1016/ j.telpol.2017.04.005

\section{Copyright Disclaimer}

Copyright for this article is retained by the author(s), with first publication rights granted to the journal.

This is an open-access article distributed under the terms and conditions of the Creative Commons Attribution license (http://creativecommons.org/licenses/by/3.0/). 